PAP

24,3

Received 16 July 2021

Revised 10 October 2021 Accepted 23 October 2021

\section{The global economic cost of coronavirus pandemic: current and future implications}

\author{
Mian M. Ajmal and Mehmood Khan \\ College of Business, Abu Dhabi University, Abu Dhabi, United Arab Emirates, and \\ Muhammad Kashif Shad \\ Management and Humanities Department, Universiti Teknologi Petronas, \\ Perak, Malaysia
}

\begin{abstract}
Purpose - The global economy is plagued by an unprecedented shock that has devastated economic growth under the coronavirus pandemic. The prolonged movement control orders, social distancing, and lockdowns have triggered the global economic downturn, disrupted the demand and supply chains, reduced the pool of workforce, and caused many jobs loss. This paper aims to analyze the global economic cost of the coronavirus pandemic, and its current and future implications.

Design/methodology/approach - Based on contingency theory, this paper provides an in-depth analysis of the current situation on the global economic cost of the COVID-19 outbreak and gives insights from an organizational perspective.

Findings - This paper found that the world has witnessed far-ranging economic consequences due to the coronavirus pandemic in four aspects: (i) decline in personal consumption; (ii) decline in the investments and stock prices in capital market; (iii) decline in government spending in developmental projects and increase in new borrowing; and (iv) decline of exports of goods to international markets.

Originality/value - The novelty lies in investigating the effects of the COVID-19 pandemic on micro and macroeconomic levels - the components of GDP, consumer behavior, business investments, government spending, and global exports. The paper suggests the need for urgent actions by the world leaders to oversee, anticipate, and manage the risks and cushion the economic consequences. It concludes that the flexibility and adaptability of leaders, effectiveness, workforce protection, efficient use of modern technology, including automation and artificial intelligence, would enhance the resilience of supply chains which will support organizations to sustain in this critical time.
\end{abstract}

Keywords COVID-19, Pandemic, Contingency theory, Economic cost, Global economy

Paper type Viewpoint

\section{Introduction}

The global economy has been thrown into a state of uncertainty caused by the COVID-19 outbreak. COVID-19 was declared a pandemic in March 2020 by the World Health Organization (WHO), which shocked societies, health systems, economies, and governments worldwide (Ali et al., 2021; Yu et al., 2021). Amid extraordinary challenges and uncertainty, and countless personal tragedies, world leaders are under pressure to make decisions on managing the immediate impact of the pandemic and its consequences and decisions that will shape the state of the world for years to come. There is no doubt that the coronavirus outbreak has significantly disrupted the momentum, initially in China and more broadly

(C) Mian M. Ajmal, Mehmood Khan and Muhammad Kashif Shad. Published in Public Administration and Policy. Published by Emerald Publishing Limited. This article is published under the Creative Commons Attribution (CC BY 4.0) license. Anyone may reproduce, distribute, translate and create derivative works of this article (for both commercial and non-commercial purposes), subject to full attribution to the original publication and authors. The full terms of this license may be seen at http:// creativecommons.org/licences/by/4.0/legalcode
Public Administration and Policy Vol. 24 No. 3,2021 pp. $290-305$ Emerald Publishing Limited 1727-2645 DOI 10.1108/PAP-10-2021-0054 
(Kraus et al., 2020). The pandemic is having a noticeable impact on global economic growth. The International Monitory Fund (IMF) stated that many countries face a multi-layered crisis that includes a health crisis, a domestic economic crisis, falling external demand, capital outflows, and a collapse in commodity prices (Congressional Research Service, 2021). It is predicted that the global economy would experience its "worst recession since the Great Depression, surpassing that seen during the global financial crisis a decade ago." The IMF estimated that the global economy could decline by 2.4 to 2.8 percent; global trade is projected to fall by 13 percent to 32 percent, and oil prices are projected to fall by 42 percent in 2020 (Sharfuddin, 2020).

In comparison, the World Bank recently forecasted a 5.2 percent contraction in global economic growth in 2020, with a 4.2 percent rebound in 2021. The World Economic Outlook report in April and June 2020 projected a decline in global GDP growth to -3.0 percent in April from 3.3 percent in January 2020. The projection was further recorded downward by 1.9 percent to -4.9 percent in June 2020 as shown in Figure 1 (Gopinath, 2020). These projections imply a cumulative loss to the global economy over two years (2020-21) of over $\$ 12$ trillion from this pandemic.

Nearly all advanced and emerging economies have their growth estimates downward or some into negative in 2020 (Maliszewska et al., 2020). This pandemic has impacted the global economy significantly due to workplace absenteeism, low production, sharp drop in travel, a decline in demand and supply, and closures of factories. In addition to the impact on macroeconomic activities, consumers typically changed their spending behavior, mainly due to decreased income and household finances and a collapse of consumer demand as millions of people stay home and postpone their non-essential expenditures. Service industries such as tourism, hospitality, air travel, cruises, and road transportation have suffered significant losses due to fewer travelers. According to Škare et al. (2021), the national economies are badly affected by travel restrictions such as international travel, domestic tourism, day visits, and segments as diverse as air transport, cruises, public transport, accommodation, cafes and restaurants, conventions, festivals, meetings, or sports events. These micro and macroeconomic factors severely damage almost every sector and ultimately lead to the global economic recession. Several countries such as New Zealand, Vietnam, Germany, Costa Rica, Thailand have done relatively well in flattening the COVID-19 curve and put their economies on a firmer footing through direct fiscal injection. Nonetheless, these direct assistance packages are causing fiscal deficit and debt-to-GDP ratio to rise. Ultimately, this will further deteriorate by bringing unemployment, income losses, inflation, and tax base shift, necessitating more drastic policy options.

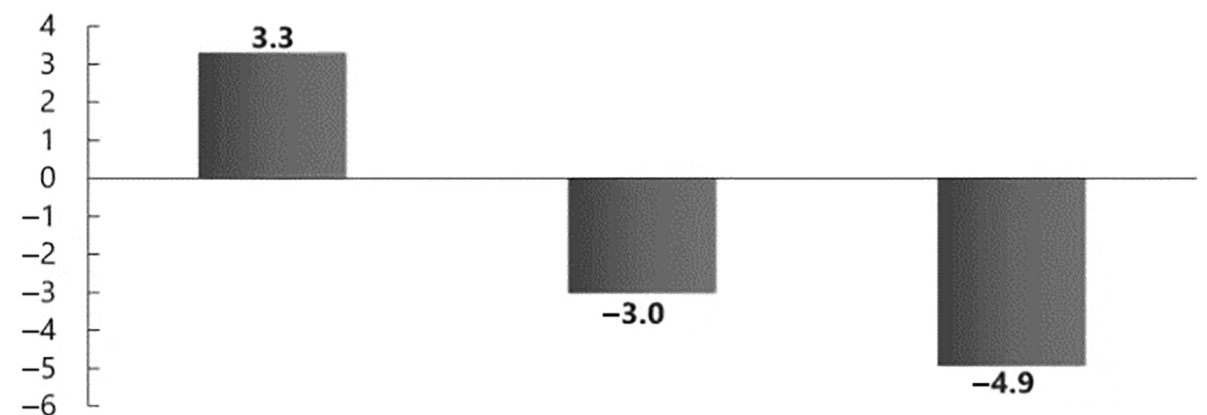

Jan. 2020

Apr. 2020
Economic cost of coronavirus pandemic

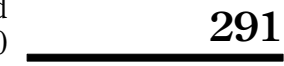


PAP

24,3

292

In this paper, the authors provide a review of the economic consequences of the COVID-19 outbreak over various sectors of the global economy. It is significant to study and understand the economic situations of developing countries with low GDP output, high debt, and dependence on oil and other essential technologies, as it is hard for them to maintain independent foreign policies in these critical times (Sharfuddin, 2020). This paper reviews the effect of prolonged movement control orders, social distancing, and lockdown practices on the world economy. It also attempts to put forward the notion of contingency theory by knowing the consequences and formulation of productive tactics and pre-planned strategies that could help organizations reduce at least the impact of the possible crisis. In a nutshell, this paper summarizes four aspects through which the economies are affected due to the COVID-19 outbreak, which are: (i) decline in the consumption behavior of people including goods and services; (ii) decline in the investments and stock prices in capital market; (iii) decline in government spending in developmental projects and increased in new borrowing; and (iv) decline in domestically produced goods to export to international markets.

\section{The COVID-19 crisis}

Coronavirus disease, now named as COVID-19 was first reported in December 2019 in Wuhan, China (Abiad et al., 2020). Since then, it has spread across the globe, and the World Health Organization has declared it a global pandemic (Kraus et al., 2020). This virus belongs to the same family of coronaviruses that caused the Severe Acute Respiratory Syndrome (SARS) outbreak in 2003 and the Middle East Respiratory Syndrome (MERS) outbreak in 2012. The estimated mortality rate of COVID-19 is around 2.1 percent, pretty lesser than 9.6 percent for SARS, 43.9 percent for Ebola, and 34.4 percent for MERS (Table 1), but substantially higher than the mortality rate of seasonal flu (0.07 percent), and AH1N1 Influenza (0.02 percent). The infection rate of COVID-19 is much higher than that of MERS, SARS, and Ebola, which spread to around 205 countries and confirmed cases exceeded over 212.5 million. More than 4.6 million deaths were reported to WHO (2021) on 10 September 2021 (Table 1).

\section{Global economy under the COVID-19 crisis}

COVID-19 initially a health crisis translated into an economic crisis that severely damaged the global economy and brought it to its knees. As a result, World's GDP is expected to decline by 2.1 percent, developing countries by 2.5 percent, and high-income countries by 1.9 percent in 2020 (Maliszewska et al., 2020). Exporting countries such as the U.S., Canada, Germany, Italy, Japan, Mexico, and South Korea's growth is highly driven by domestic resources. They are projected to be the most negatively affected by the COVID-19 crisis. Also, service-oriented economies are badly affected; nearly half of the global workforce lost livelihoods.

Moreover, social distancing, travel restrictions, and quarantines caused heavy losses to all significant economies reliant on the tourism industry, including the U.S., Greece, Portugal,

Table 1.

Fatality and infection rates of COVID-19 and other diseases

\begin{tabular}{lrrc}
\hline Diseases & Total Cases & Total Deaths & Fatality Rate \% \\
\hline COVID-19 or Corona Virus & $228,734,606$ & $4,697,994$ & 2.1 \\
U.S. Seasonal Flu & $13,000,000$ & 10,000 & 0.07 \\
SARS & 8,437 & 813 & 9.6 \\
MERS & 2,494 & 858 & 34.4 \\
Ebola & 34,453 & 15,158 & 0.9 \\
AH1N1 & $762,630,000$ & 284,500 & 0.02 \\
Source: WHO (2021). & & &
\end{tabular}


Spain, Malaysia, the Philippines, and Saudi Arabia. COVID-19 had affected a broad range of countries, including the G7 countries, which jointly contribute 60 percent of world supply and demand, 65 percent of world manufacturing, and 41 percent of world exports. This pandemic has jeopardized overall economies, including large, small, developed, and developing economies. Romano (2020) found that the pandemic has badly affected Australia's economy, contributing around a 15 percent reduction in their GDP.

IMF's World Economic Outlook report stated that the COVID-19 is escalating economic costs day by day. The projected cumulative loss to the global economy over two years (2020-21) would be over $\$ 12$ trillion. Congressional Research Service Report has identified three aspects through which the global economy is being affected - decline in the supply chains, reduced demand for goods in general, including imports, and reduced trade with exporters (Congressional Research Service, 2021). Nicola et al. (2020) also summarized three main channels of the pandemic's likely effects on the global economy - primary sectors, including industries involved in the extraction of raw materials, secondary sectors involved in producing finished products, and tertiary sectors including all service provision industries. On the other hand, Arezki and Nguyen (2020) discussed four channels that hurt the economies of North Africa and the Middle East. These include disruptions in oil price, value chain, tourism, and travel. Meninno and Wolff (2020) looked at the economic consequences of closing borders of the European Union (EU). They suggested that stopping cross-border travel would lead to a significant disruption of economic activity in the EU. Other researchers, such as Abiad et al. (2020), argued that economic activities in developing Asia, including China, are being affected in several aspects. These include a temporary decline in domestic consumption and investments in business activities, declines in tourism and business travel, a decrease in production and trade activities, disruptions in the supply side, and effects on health such as increased disease and mortality and shifts in health care spending. Inevitably, the most important channels through which the global economic effects of the pandemic were spread through a sharp decline in consumption, investments, government spending, and decline in the exports (Figure 2).

In an attempt to understand the negative effect of COVID-19 on the global economy in terms of GDP, four aspects are summarized: (i) focusing on the decline in the consumption expenditures, which include goods and services; (ii) capital investments and stock prices in markets; (iii) government spending including central government expenditure in national defense and non-defense, as well as State and local government's expenditure estimates; and (iv) exports including goods and services made domestically and purchased by foreigners.

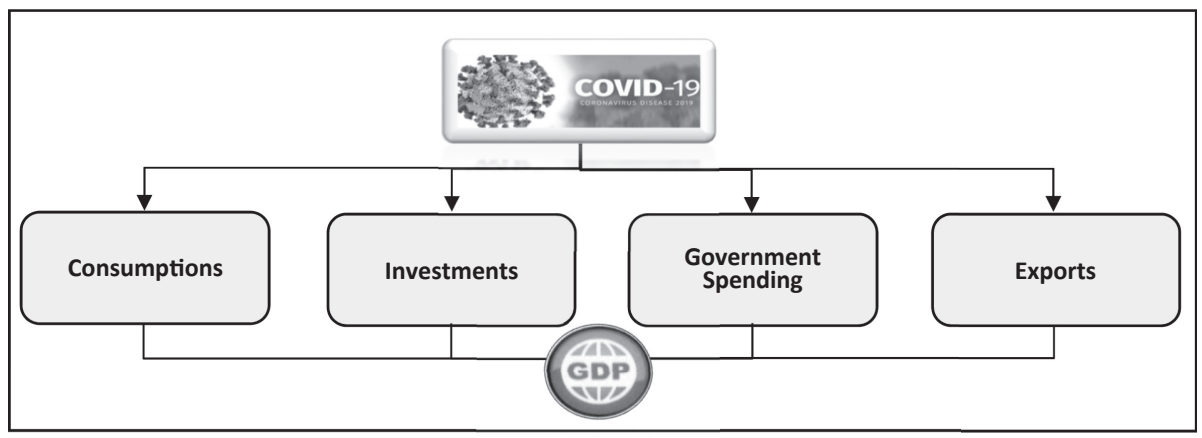

Source(s): By authors
Economic cost of coronavirus pandemic

Figure 2. The impacts of COVID19 on GDP components 
PAP

24,3

294

\section{A. Impact on personal consumption}

The leading component for the decline in GDP due to COVID-19 is the downward curve of people's consumption behavior. The pandemic badly damaged economic growth due to higher production costs, low labor supply, and reduced consumption. Most people have reduced their spending as they are worried about their household finances due to the economic recession. According to Nicola et al. (2020), China's quarantine and social distancing practices reduced industrial manufacturing, people's consumption, demand, and utilization of goods and services. The immediate and direct impact of the COVID-19 outbreak was felt on the shutdown of factories and businesses, resulting in a sharp and immediate decline of production in the economy. The crisis then amplified simultaneous supply chains disruptions of necessary production inputs and an immediate drop in demand. The demand for goods and services dropped as consumers saved for emergencies. As COVID-19 spreads worldwide, the international demand for countries' goods and services slumped significantly, reducing production.

According to Baker et al. (2020), personal consumption contributes almost 70 percent to the U.S. economy annually, and hence it is considered a significant economic indicator and workhorse that drives economic growth. The demand for good consumption, both durable and non-durable goods, declined continuously all over the world. Durable goods such as automobiles, household equipment, furnishings, and other durables saw a significant decline over the last quarter due to the closure of economic activities and uncertainty in the global economic environment and household income. At the beginning of the COVID-19 outbreak, household consumption of non-durable goods, including food and beverages, clothing and footwear, fuel, and other nondurable goods, increased dramatically. This increase is led by panic buying in an attempt to store needed household stuff because of fear of shortage and closure of the retailers. Hence, household expenditures increased by approximately 50 percent between February 26 and March 11, 2019 (Baker et al., 2020). According to the U.S. Bureau of Economic Analysis (2020), personal expenditure fell around 7.6 percent during the first quarter of 2020, which is the most significant decline in the history of the U.S. (Figure 3).

Baker et al. (2020) stated that as the pandemic spread increased, the household began to alter their typical spending across several significant categories drastically. Initially, spending increased sharply, particularly in retail, credit card spending, and food items.

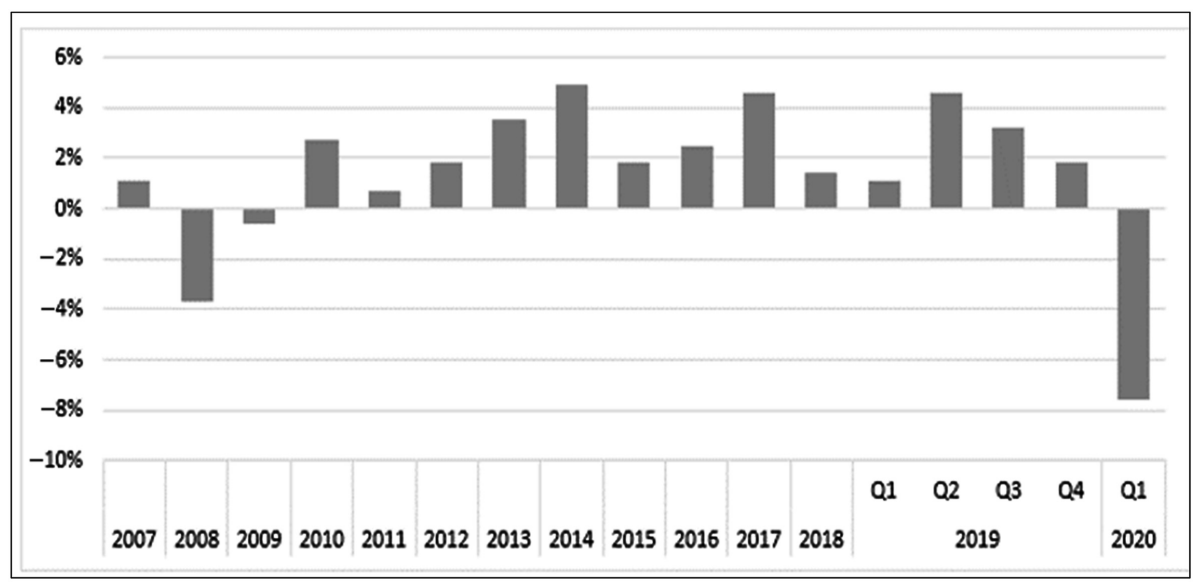

Source(s): U.S. Bureau of Economic Analysis (2020)
Figure 3.

U.S. personal consumption expenditures 
A sharp decrease followed this in overall spending - retail spending, restaurant spending, air travel spending, food delivery spending, public transit spending, and credit card spending.

\section{B. Impact on investment and stock prices in capital market}

Another important aspect through which the global economic system is affected is likely to reduce investments and stock prices in capital markets. Globally stock markets have crashed dramatically and lost 15 trillion of the value of high-risk assets, and economists are anticipating a worse economic crisis than the great recession of 2008-2009 (Kraus et al., 2020). On the other hand, the investors in emerging markets pulled out US $\$ 5.3$ billion of stocks which is the highest level in 30 weeks (Alnasrawi et al., 2020). Similarly, the global demand and supply of durable goods stocks declined severely due to a decline in global economic activities.

In the same context, New York Wall Street has incurred heavy losses. U.S. stock market index, namely Standard and Poor (S\&P) that measures the stock performance of 500 large companies on the U.S. stock exchange, the Dow Jones Industrial Average, and the Nikkei 225 (Stock market index for Tokyo stock exchange), fell dramatically. S\&P index lost 34.56 percent over March, its worst month since 2008. The Dow Jones Industrial index lost nearly 35 percent of its value in March 2020, and the Nikkei 225 lost 28 percent of its value (Bloomberg, 2020) (Figure 4). All these stock markets lost billions of dollars in value until the U.S. government secured the Coronavirus Aid, Relief, and Economic Security (CARES) Act, with the indexes raised to -19.3 percent for S\&P, -13.3 percent for Dow Jones, and -5.2 percent for Nikkei index in July 2020 (Nicola et al., 2020).

Furthermore, the financial markets indices of other countries also fell drastically, and investors in these markets cannot predict where to invest in this vulnerable period. According to Ozili (2020), significant stocks such as Safaricom declined by 5.4 percent, and Kenya Commercial Bank Group (KCB) stock's value declined by 7 percent in Nairobi Stock Exchange on the first day the first COVID case was found. Similarly, in Casablanca Stock Exchange Morocco, the share prices dropped immediately after confirmed cases, leading to a recession in the equity investment market. In China, the Shanghai stock market fell by 2 percent, and Hong Kong stock market was down by more than 3.6 percent, Sydney Stock Exchange fell by more than 7 percent (Alnasrawi et al., 2020). In Gulf stock exchanges, the most considerable losses are suffered by oil and gas companies. Aramco lost a tenth of the
Economic cost of coronavirus pandemic

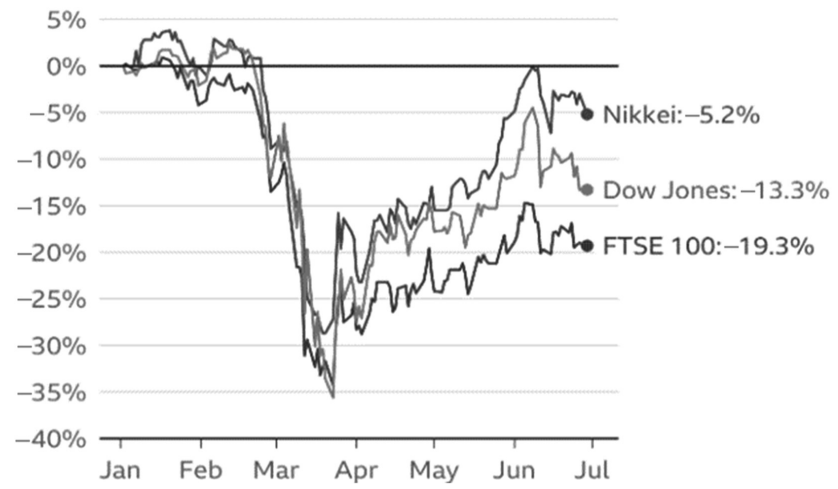

Source(s): Bloomberg (2020)

Figure 4. Stock markets performance during COVID crisis 
PAP

24,3

296

value of its shares in its trading. Dubai's financial market general index fell by 5 percent, trading at its lowest since 2013. National Bank of Dubai (NBD) was among the biggest fallers, dropping 10 percent. According to the World Cities Report (2020), the largest companies in the Gulf region lost around US $\$ 420$ billion in market capital during the first quarter of 2020. Moreover, the losses recorded by the wealth of these companies are equivalent to 8 percent of the region's total wealth (Alnasrawi et al., 2020).

\section{Impact on government spending}

Government spending includes government consumption, investment, and transfer payments to acquire goods and services to create future benefits. Due to the COVID-19 crisis, more than three times the local government's budget is spent on community hygienic and health and care services. Moreover, most of the countries abandoned traditional borrowing to increase fiscal spending to sustain economic growth. In some emerging economies, governments adopted special programs to support unemployed workers and social safety nets (Kraus et al., 2020). Eventually, the local government's revenue collection through taxation, transport, fines and penalties, rents, and taxes from council properties suffered badly (Sharfuddin, 2020). Sales tax is one of the most important sources of revenue for local governments. It is most likely to be affected by the economic pause and social distancing measures implemented to control COVID-19 (Haji, 2021). The closure of retail and entertainment venues, restaurants, and shopping malls and the decline in gasoline prices have begun to impact sales tax revenues and increase the fiscal deficit significantly. Other than that, the increase in the fiscal deficit was instigated as the central governments around the world have adopted measures to support economic growth. These measures broadly include tax cuts and tax deferrals, wage and income supplements to individuals, including expanding unemployment insurance, and other payments to businesses (Congressional Research Service, 2021). To reduce the fiscal deficit and fill the gap between revenue and spending, the government subsequently borrows money, increasing national debt (Ehigiamusoe and Lean, 2020). According to the recent Congressional Research Service Report published in September 2020, IMF has estimated the increase in borrowing by governments globally to rise from 3.9 percent of global GDP in 2019 to 13.9 percent in 2020, as shown in Figure 5.

The U.S. fiscal deficit to GDP is projected to rise from 6.3 percent to 23.8 percent, the highest ratio for any country or region. BBC reported on 9 July 2020 that according to the office for Budget Responsibility (OBR) UK’s government estimated deficit was around $£ 55$ billion in 2019. However, it is projected to increase to around $£ 300 \mathrm{bn}$ in 2020 , more than 10 percent of their annual GDP. Similarly, the Canadian government estimated their budget deficit to C $\$ 314.0$ billion in 2020-21, 12.7 percent of Canada's GDP and would be the most significant federal deficit on record. For developing economies, the fiscal deficit to GDP ratio is projected to rise from 4.9 percent to 10.6 percent, significantly increasing their debt burden and raising prospects of defaults (Congressional Research Service, 2021). Among the Asian economies, the fiscal deficit to GDP ratio is projected to rise from 6.0 percent in 2019 to 11.4 percent in 2020. The ratio for Middle Eastern economies is projected to rise from 3.9 percent to 9.8 percent in 2020. In summary, IMF assumed that higher debt levels could become unmanageable, particularly for developing economies, and activate prolonged recession. Ehigiamusoe and Lean (2020) provided empirical evidence that fiscal deficit negatively impacts economic growth by decreasing productivity and capital growth.

\section{Impact on net exports}

The global economy has received a massive hit from COVID-19, and the volume of goods in global trade fell drastically, affecting all sectors of the economy (Haji, 2021; Cepal, 2020). 
Fiscal balance, \% share of GDP

$23.8 \%$

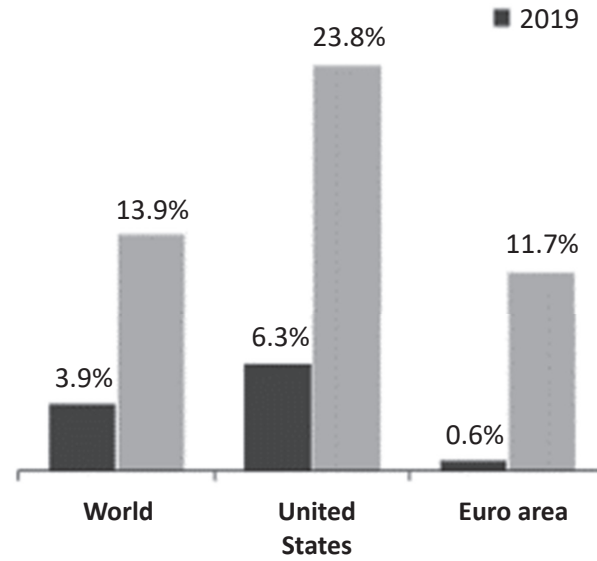

Source(s): Congressional Research Service (2020)
Economic cost

of coronavirus

pandemic

Global Economic Prospects by World Bank stated that the COVID-19 pandemic had affected international travel and global value chains, which caused global trade to decline by 13 percent in 2020, which is more than that it did during the global financial crisis and World War II (World Bank Group, 2020) (Figure 6). This fall in trade negatively impacts not only export-oriented but also importing countries. As the country could not export its finished goods, the imports of material declined. More broadly, the decline in exports occurred as a result of a slowdown in three channels of trade: (i) disruptions in the global supply chain network; (ii) reduction in demand for goods in general including imports; and (iii) reduction in

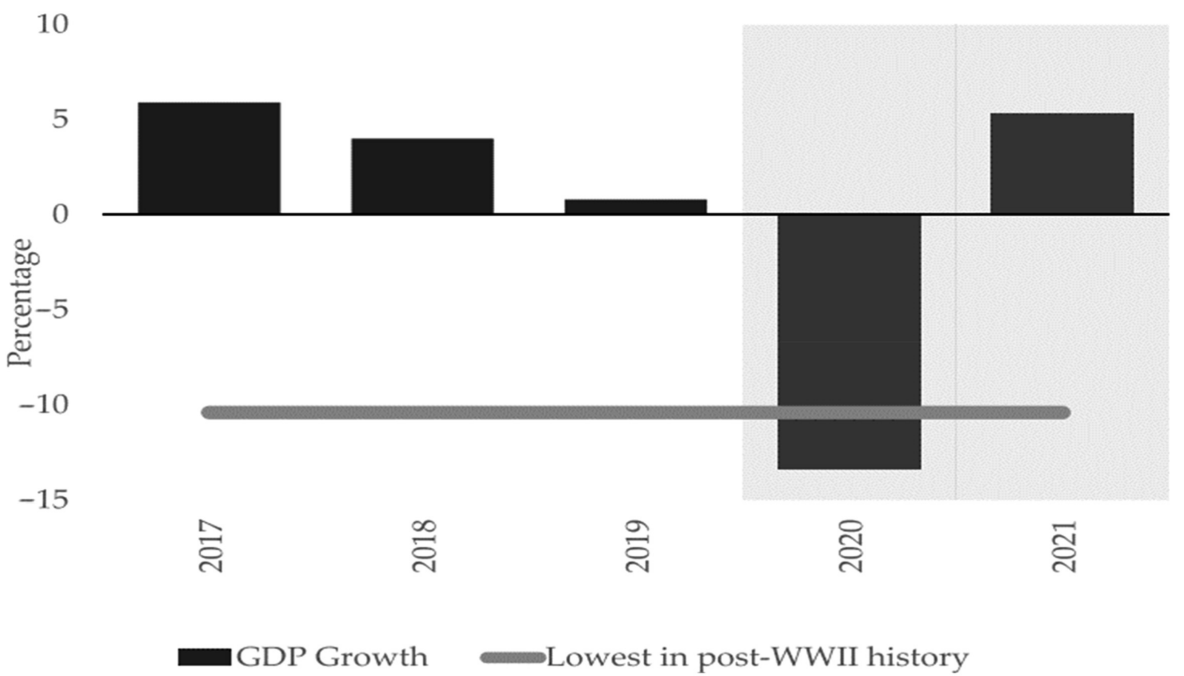

Source(s): World Bank Group (2020)

Figure 6. Global trade growth 
PAP

24,3

298

trade with commodity exporters, which, in turn, reduced their imports and negatively affected trade and economic activities of exporters (Congressional Research Service, 2021). Amongst the most developed and significant economies such as Canada, the U.S., UK, Germany, France, Italy, Japan, South Korea, China, Hong Kong, India, Indonesia, Russia, Netherlands, and Singapore are highly dependent on trade. Exporters are now projected to be the most negatively affected as a result of a slowdown in trade. The World Bank has also predicted that these economies will likely experience slow growth in the first half of 2020 . Vidya and Prabheesh (2020) empirically validated the trade volume of the above-mentioned major trade economies. They found that the COVID crisis has badly damaged the trading density of these areas, which has been reduced from 0.833 to 0.429 . Congressional Research Service Report (2021) indicated that in July 2020, U.S. exports of goods and services had fallen by 17.5 percent compared with the comparable with July 2019, and the imports of goods and services had fallen by 13.8 percent, reflecting the overall decline in global trade. Cepal (2020) indicated that the global trade has collapsed, and the volume of goods trade in the global economy fell by 17.7 percent in May 2020 compared with the same month in 2019.

\section{Contingency theory}

Contingency theory is well established in leadership and management literature that describes different situations by interacting with effective leadership styles (Arifah et al., 2018). This theory presents the dynamics of interaction between influential leaders and workers in facing any situation. The occurrence of any crisis or uncertainty affects the demand and supply chains of products and services that can damage the entire economy at both micro and macro level and pose a threat to global economic growth (Ghosal and Ye, 2019). Past studies on harsh conditions, such as Bradley et al. (2011), indicated that the organization needs to develop a contingency plan that can help them sustain their vital resources during a crisis. Ineffective business continuity planning along with poor risk management accounts for business failure and leads to bankruptcy. According to Obrenovic et al. (2020), organizations without adequate contingency and business continuity plans will suffer significant post-crisis financial losses. Therefore, successful organizations have to put contingency and risk management plans in place onset.

Kim and Kreps (2020) stated that at the beginning of the COVID pandemic, the U.S. government violated the notion of contingency theory by failing to adopt creative and responsive strategies to address the threat. Rather, the U.S. federal government repeatedly downplayed the risk from the coronavirus, telling the public that the viral risk would probably go away on its own. Even though contingency and risk management plans exist at every stage of the organization, the sudden shock and failure in performance caused by the crisis or pandemic show the inappropriate or ineffective implementation of the current strategic programs. Instead, the organizations may have contingency plans or risk management departments but do not have practical value (Obrenovic et al., 2020). The coronavirus outbreak is unprecedent and caused economic crisis for which the global organizations were not prepared. Therefore, global leaders need to focus on learning the immense magnitude of such a crisis in the future and carefully evaluate the economic actors and business processes. A more comprehensive understanding of the calamities and consequences of the potential crisis may help organizations formulate various strategies to cope with such events. Knowing the consequences and formulation of productive tactics and pre-planned strategies could help organizations reduce at least the impact of the possible crisis.

The contingency theory embraces several concepts relevant to the understanding and suggests the organizations' strategies to cope with the crisis. Lartey (2020) identified four critical constructs of contingency theory - adaptation, effectiveness, equifinality, and 
congruency. Tosi and Slocum (1984) conceptualized that organizations need to sharpen three dimensions - effectiveness, environment, and congruency. A recent study by Moretto and Caniato (2021) provided research directions based on contingency theory in the supply chain finance domain to mitigate financial disruption amid COVID-19. According to the authors, COVID-19 has introduced new contingent variables (new solutions), new response variables (new objectives), and new performance variables (new benefits). Obrenovic et al. (2020) argued that organizations with a financial contingency plan, diversified supply chain network, distributed leadership and workforce, and advanced digitalization would sustain themselves during the emergency and disastrous situations. Therefore, we build on these premises and theorize that the flexibility and adaptive culture, effectiveness, workforce protection, intelligent use of technology and cloud computing, and use of automation and artificial intelligence to enhance the resilience of supply chains will support organizations to survive during the coronavirus pandemic (Table 2).

\section{A) Adaptability}

Adaptability and flexibility of leaders to the potential changes in the environment is the fundamental principle of contingency theory. Contingency theory supports identifying the related aspects of any circumstance and enabling the system to adapt in case of any eventuality (Lartey, 2020). Effective leadership must adapt to a modified level of operations and maximize output without fostering burnout during prolonged crises such as the COVID pandemic. The leadership that preserves an open-door policy for team members, a resilient and flexible mindset, is more adaptable and can deal effectively with unsafe conditions (Obrenovic et al., 2020). In responding to the current pandemic, countries need to put adaptive governance mechanisms into practice and swiftly take action (Janssen and Van Der Voort, 2020).

To reduce the financial impacts of the coronavirus pandemic, the top management in the organizations needs to focus on consumer preferences and restructure their businesses for the next normal. COVID-19 has forced many businesses from their comfort zone, testing the limits of remote working and redesigning operations to encourage health and safety practices. The adaptability of the management to new normal and managing new risks emerged due to the recent pandemic in an organization, its processes, and its policies should result in resilience and growth, not fragility and pain.

\section{B) Effectiveness}

Organizational effectiveness requires a business strategy designed to improve efficiency without compromising the quality of goods or services. Lartey (2020) indicated that effectiveness is a central pillar of the contingency theory as it is essential in the adaptation and survival of the organization to meet its goals. There are many ways to achieve effectiveness - stable and secure work experience and job security, trust relationships and employees satisfaction, individual purpose and contribution, quality services, use of technology, performance measurement through correct metrics, and social cohesion and inclusion. As ways of work shifted dramatically with the COVID-19 pandemic, the organization's top management needs to obtain new ideas to help reduce costs, sustain trust and acknowledge employee efforts, and improve product and quality customer services.

\section{C) Workforce protection}

Workforce protection is a notion embedded in contingency theory that represents the leadership style to get the best from their workers, creating flexible and suitable working structures that benefit everyone (Obrenovic et al., 2020). The organizations witnessed
Economic cost of coronavirus pandemic 
PAP

24,3

Adaptability

Leader's flexibility and adaptability to the potential changes in the environment

\section{0}

- Building a resilient mindset

- Rapidly develop responses

- Dedicate/create new channels to share updates with your people and communicate priorities

- Maintain an open-door policy for team members to share honest feelings

- Accommodate agile/adaptive operating structures

- Institute lessons learned sessions for teams to share learnings around new ways of work

- Encourage employees to create new relationships and working groups

- Improve employee's engagement and performance

- Uphold employees to their tasks and responsibilities

- Work on quality services or products

- Make use of digitization and advance technology

- Measure and analyze your project, process, or other systems by correct metrics

\section{Workforce Protection \\ Actively contribute to protecting workforce value}

- Understand the impact on people and priorities

- Prevent stigma and discrimination in the workplace

- Unlock the potential for teaming and collaboration

- Safeguard confidentiality

- Prioritize employee well being

- Avoid workforce bias

- Empower team
Use of
Technology
Demonstrate the importance of digital readiness

\section{Table 2.}

Critical constructs of contingency theory
Source: By authors.
- Take a human-centered and inclusive approach to technology governance

- Improve decision making through better data analytics

- Improve remote work

- Improve collaboration and communication

- Build necessary infrastructure to support a digitized world and stay current in the latest technology

- Reconfigure supply chain network to real-time

- Make use of technology to strengthen resilience within your supply chains

restrictions due to the pandemic, including remote work policies and flexible workforce arrangements which required the global organization to improve their IT systems for effective communication between management, employees, suppliers, and customers (Kilpatrick and Barter, 2020). Most of the organizations worldwide have started resuming work. Therefore, leaders need to consider restart business operations, improve their 
workforce's well-being, and confidentiality amid the ongoing pandemic. The top management requires additional attention to workforce planning and the quality of goods or services they provide to the market (Kilpatrick and Barter, 2020).
Economic cost of coronavirus pandemic

\section{D) Use of technology}

Contingency theory believes that there is no "one right way" because it all depends on the situation (Arifah et al., 2018). The leadership in the organization needs to think afresh in any situation and decide the best next step to take. The recent restriction due to the pandemic forced workers to work from home, making workers and organizations more dependent on technology. The technological advancement of the fourth industrial revolution with emerging and enabling technologies including 5G, Artificial Intelligence (AI), machine learning, big data, internet of things (IoT), blockchain, virtual reality, and cloud computing are bringing drastic impact on improving the businesses by enhancing the accuracy of data and encouraging data sharing (Khan, 2020). The use of digital technology-enabled workforce to work from their homes and handle their professional tasks from their smartphone, tablets, laptops, and computer to keep businesses afloat during the current crisis. Moreover, the businesses that have designed their solutions to use the full potential of cloud computing, such as accessing digital payment methods, will strengthen their supply chain nexus.

\section{Discussion and managerial implications}

The world is witnessing far-ranging economic consequences due to the coronavirus pandemic, and the end is not yet in sight. Disruptions in the supply chain network, including imports and exports, inflation, lack of investment opportunities, fluctuation in the oil prices and stock market affected the US $\$ 90$ trillion global economy beyond anything experienced in nearly a century (Congressional Research Service, 2021). Global trade has collapsed, and the volume of goods trade fell sharply due to the global recession, which added to the extent of global economic disturbance. The value of equity markets, investors, earnings, and households employment have been affected within the countries. The destruction in the global economy as a result of the current pandemic is apparent, representing the most considerable economic shock the world has been experiencing in decades. COVID-19 crisis highlights the need for urgent actions by the world leaders to oversee, anticipate, and manage the risks and cushion the economic consequences. Critical decisions need to be taken, but time is limited. During disordered situations, the organization needs to diagnose the business environment. They need to identify the level of disorder in their business activities constantly. This is important as the various levels of turmoil require organizations to adopt different coping strategies. By identifying the level of disorder and diagnosing the needs and tastes, the organizations may turn crises into new business opportunities.

Based on contingency theory, leaders and managers can quickly take innovative moves, respond to unforeseen situations, and willingly accept certain risks. Avoid facing risks may push them out of the market. Innovation is the key; when businesses are disrupted, the leaders should think of other business models to face various pandemic stages, including shock, adaptation, recovery, and the new normal. Leaders and managers should continue developing financial and managerial responses and other safety plans to mitigate the impacts of the COVID-19 crisis and return to normal business operations. The organizations with governance structures that are better adapted to predictable environments observe significant changes in management and leadership practices (Moretto and Caniato, 2021). Maher et al. (2020) proposed a RISE (Resilience, Intentions, Sustain and Endurance) framework that aims to help public and non-profit entities to navigate the economic effects of 
PAP

24,3

302

COVID-19. The organizational actions can be classified into four stages such as resilience or flexibility to react to the uncertainty, intentions to take immediate actions to mitigate the negative financial impacts, sustain the actions to be taken for organizations survival and stability, and endurance of their operation against future fiscal emergencies and seize new opportunities.

Most of the organizations have now enforced their online activities or explored alternative markets. The essential part for the organization in a chaotic situation is to learn from their worst experiences. They should be flexible and constantly update their strategies to deal with the chaotic environment. In addition, organizations need to generate self-renewal and agility by upgrading their strengths and developing resources by coping with new demands of the environment. Agility, scalability, and automation will be the watchwords for this new era of business, and now those with these capabilities will be the winners. In the light of the contingency theory, businesses that focus on the principle of adaptability and flexibility and have designed their solutions to use the full potential of the technology such as cloud computing, automation, and artificial intelligence, will not be buckled under the pressure. For instance, the cloud gives businesses easy access to digital payment methods. This will enable companies to continue working by rapidly and securely providing access to business applications to their employees working at home, providing financial flexibility, and enhancing the resilience of their supply chains.

Conclusively, the COVID-19 crisis provides prominent lessons to world leaders, businesses, economists, policymakers, and academic researchers about the effects of global change. Hence, this paper would be highly relevant for academia and management alike. Academically, it is essential for two reasons. First, there is limited research investigating the effects of the COVID-19 crisis on the components of GDP, including consumer behavior, business investments, government spending, and exports of countries. Second, the coronavirus pandemic is still ongoing; as a result, the economy changes significantly. Understanding how countries change after pandemic and face the second wave allows for an improved understanding of global changing economies. In line with that, this paper focuses on contingency theory and theorize that to create a genuinely sustainable economy, it is crucial for world leaders to have a culture of adaptability, effectiveness, workforce protection, and use of automation and artificial intelligence to enhance resilience of supply chains to support and sustain organizations during pandemic. The paper is of managerial relevance because the world is severely affected by the pandemic. An understanding of what happened during and as a consequence of this pandemic makes it possible to know how world leaders can react to a pandemic that is going on and has not fully recovered yet. There is still a great deal of uncertainty about COVID-19, which makes it very concerning.

\section{Conclusion}

The COVID-19 pandemic has spread profoundly, infected millions of people and halt economic activities globally. The unprecedented collapse in the global economic system is caused due to widespread disruption in demand and supply chains, evacuation of millions of workers, slowing global trade, shipment, and travel-related restrictions imposed by local governments. The challenge is now to collectively learn from this global crisis and accelerate the global economic transformation. In this paper, the authors delve into the existing literature to generate new knowledge regarding the impact of the COVID-19 crisis on the global GDP. The novelty lies in the investigation of the disproportionate effect of the current pandemic on the global economy through (i) decline in the consumption behavior of people; (ii) decline in the investments and stock prices in capital market; (iii) decline in government spending in developmental projects and increase in new borrowing; and (iv) decline in export 
of goods to international markets. Based on contingency theory, this paper suggests the need for urgent actions by world leaders to overcome the economic consequences of the pandemic. As longer the COVID-19 persists, the more difficult it would be for global firms to survive. This, in turn, spillover the aggregate growth rate of the global economy. This paper concludes that the flexibility and adaptability of leaders, effectiveness, workforce protection, and the efficient use of modern technologies to enhance the resilience of supply chains will support organizations to sustain their businesses. Future researchers can test the proposed conceptual framework by taking real-time data and validate the impact of COVID-19 on the components of global GDP, especially on the emerging economies.

\section{References}

Abiad, A., Arao, R.M., Dagli, S., Ferrarini, B., Noy, I., Osewe, P.L., Pagaduan, J., Park, D. and Platitas, R. (2020), "The economic impact of the COVID-19 outbreak on developing Asia", Asian Development Bank Briefs No. 128. doi: 10.22617/BRF200096.

Ali, M., de Azevedo, A.R.G., Marvila, M.T., Khan, M.I., Memon, A.M., Masood, F., Almahbashi, N.M.Y., Shad, M.K., Khan, M.A., Fediuk, R., Timokhin, R., Borovkov, A. and Haq, I.U. (2021), "The influence of COVID-19-induced daily activities on health parameters - a case study in Malaysia", Sustainability, Vol. 13 No. 13, pp. 1-22.

Alnasrawi, S.J., Abed, H.A. and Muslm, H.S. (2020), "Impact of COVID19 outbreak on the global economy: a case of Iraq", Journal of Talent Development and Excellence, Vol. 12 No. 2, pp. 2910-2926.

Arezki, R. and Nguyen, H. (2020), "Novel coronavirus hurts the Middle East and North Africa through many channels", in Baldwin, R. and Weder di Mauro, B. (Eds), Economics in the Time of COVID-19, Centre for Economic Policy Research Press, UK, pp. 53-58.

Arifah, A.R., Tariq, M., Rosliza, A.M. and Juni, M.H. (2018), "Leadership theories in disease outbreak management", International Journal of Public Health and Clinical Sciences, Vol. 5 No. 2, pp. 1-16.

Baker, S.R., Farrokhnia, R.A., Meyer, S., Pagel, M. and Yannelis, C. (2020), "How does household spending respond to an epidemic? Consumption during the 2020 COVID-19 pandemic", The Review of Asset Pricing Studies, Vol. 10 No. 4, pp. 834-862.

Bloomberg (2020), "Stock markets performance during COVID crisis", available at: https://www.rethinkingthefuture.com/covid-and-architecture/a4153-the-effects-of-economy-on-architecturalpractice-post-lockdown/ (accessed 10 October 2021).

Bradley, S.W., Shepherd, D.A. and Wiklund, J. (2011), "The importance of slack for new organizations facing 'tough 'environments", Journal of Management Studies, Vol. 48 No. 5, pp. 1071-1097.

Cepal, N. (2020), The Effects of the Coronavirus Disease (COVID-19) Pandemic on International Trade and Logistics, Special Report COVID-19, No. 6, Economic Commission for Latin America and the Caribbean, available at: https://repositorio.cepal.org/bitstream/handle/11362/45878/1/S2000496_ en.pdf (accessed 15 September 2021).

Congressional Research Service (2020), "Global economic effects of COVID-19", available at: https:// crsreports.congress.gov/product/pdf/R/R46270/58 (accessed 10 October 2021).

Congressional Research Service (2021), "Global economic effects of COVID-19", available at https://fas. org/sgp/crs/row/R46270.pdf (accessed 10 October 2021).

Ehigiamusoe, K.U. and Lean, H.H. (2020), "The role of deficit and debt in financing growth in West Africa”, Journal of Policy Modeling, Vol. 42 No. 1, pp. 216-234.

Ghosal, V. and Ye, Y. (2019), "The impact of uncertainty on the number of businesses", Journal of Economics and Business, Vol. 105, pp. 1-20.

Gopinath, G. (2020), "Reopening from the great lockdown: uneven and uncertain recovery", [Blog], available at: https://blogs.imf.org/2020/06/24/reopening-from-the-great-lockdown-uneven-anduncertain-recovery/ (accessed 10 October 2021). 
PAP

24,3

\section{4}

Haji, S.H.H. (2021), "The effects of COVID-19 pandemic on the government revenue in the extractive industry in Tanzania", Journal of Economics, Management and Trade, Vol. 27 No. 3, pp. 12-29.

Janssen, M. and Van Der Voort, H. (2020), "Agile and adaptive governance in crisis response: lessons from the COVID-19 pandemic", International Journal of Information Management, Vol. 55, pp. 1-7.

Khan, M.K. (2020), "Technological advancements and 2020", Telecommunication Systems, Vol. 73, pp. 1-2.

Kilpatrick, J. and Barter, L. (2020), “COVID-19: managing supply chain risk and disruption”, Deloitte report, available at: https://www2.deloitte.com/content/dam/Deloitte/ca/Documents/finance/ Supply-Chain_POV_EN_FINAL-AODA.pdf (accessed 10 October 2021).

Kim, D.K.D. and Kreps, G.L. (2020), "An analysis of government communication in the United States during the COVID-19 pandemic: recommendations for effective government health risk communication”, World Medical \& Health Policy, Vol. 12 No. 4, pp. 398-412.

Kraus, S., Clauss, T., Breier, M., Gast, J., Zardini, A. and Tiberius, V. (2020), "The economics of COVID19: initial empirical evidence on how family firms in five European countries cope with the corona crisis", International Journal of Entrepreneurial Behavior and Research, Vol. 26 No. 5, pp. 1067-1092.

Lartey, F.M. (2020), "Chaos, complexity, and contingency theories: a comparative analysis and application to the 21st century organization", Journal of Business Administration Research, Vol. 9 No. 1, pp. 44-51.

Maher, C.S., Hoang, T. and Hindery, A. (2020), "Fiscal responses to COVID-19: evidence from local governments and non-profits", Public Administration Review, Vol. 80 No. 4, pp. 644-650.

Maliszewska, M., Mattoo, A. and Van Der Mensbrugghe, D. (2020), "The potential impact of COVID-19 on GDP and trade: a preliminary assessment", World Bank Policy Research Working Paper 9211.

Meninno, R. and Wolff, G. (2020), "As coronavirus spreads, can the EU afford to close its borders?”, in Baldwin, R. and Weder di Mauro, B. (Eds), Economics in the Time of COVID-19, Centre for Economic Policy Research Press, UK, pp. 87-92.

Moretto, A. and Caniato, F. (2021), "Can supply chain finance help mitigate the financial disruption brought by Covid-19?", Journal of Purchasing and Supply Management, Vol. 27 No. 4, pp. 1-10.

Nicola, M., Alsafi, Z., Sohrabi, C., Kerwan, A., Al-Jabir, A., Iosifidis, C., Agha, M. and Agha, R. (2020), "The socio-economic implications of the coronavirus pandemic (COVID-19): a review", International Journal of Surgery, Vol. 78, pp. 185-193.

Obrenovic, B., Du, J., Godinic, D., Tsoy, D., Khan, M.A.S. and Jakhongirov, I. (2020), "Sustaining enterprise operations and productivity during the COVID-19 pandemic: enterprise effectiveness and sustainability model", Sustainability, Vol. 12 No. 15, pp. 1-27.

Ozili, P. (2020), "COVID-19 in Africa: socio-economic impact, policy response and opportunities", International Journal of Sociology and Social Policy, ahead-of-print, doi: 10.1108/IJSSP-052020-0171.

Romano, F. (2020), "An estimate of the economic impact of COVID-19 on Australia", available at: https://papers.ssrn.com/sol3/papers.cfm?abstract_id =3581382 (accessed 10 September 2021).

Sharfuddin, S. (2020), “The world after Covid-19”, The Round Table, Vol. 109 No. 3, pp. 247-257.

Škare, M., Soriano, D.R. and Porada-Rochoń, M. (2021), "Impact of COVID-19 on the travel and tourism industry", Technological Forecasting and Social Change, Vol. 163, pp. 1-14. doi: 10.1016/j. techfore.2020.120469.

Tosi, H.L., Jr and Slocum, J.W., Jr (1984), “Contingency theory: some suggested directions”, Journal of Management, Vol. 10 No. 1, pp. 9-26. 
U.S. Bureau of Economic Analysis (2020), "Measuring the impact of Covid-19 on the US economy", available at: https://www.televisory.com/blogs/-/blogs/measuring-the-impact-of-covid-19-on-theus-economy (accessed 10 September 2021).

Vidya, C.T. and Prabheesh, K.P. (2020), "Implications of COVID-19 pandemic on the global trade networks", Emerging Markets Finance and Trade, Vol. 56 No. 10, pp. 2408-2421.

World Bank Group (2020), "Global economic prospects, a World Bank Group flagship report", available at: https://www.worldbank.org/en/publication/global-economic-prospects (accessed 10 October 2021).

World Cities Report (2020), "The value of sustainable urbanization", available at: https://thinkcity.com. my/wp/wp-content/uploads/2020/11/WCR-2020_print_Complete-1_compressed.pdf (accessed 11 October 2021).

World Health Organization (WHO) (2021), "WHO Coronavirus (COVID-19) Dashboard (September 2021)", available at: https://covid19.who.int/ (accessed 10 October 2021).

Yu, Z., Razzaq, A., Rehman, A., Shah, A., Jameel, K. and Mor, R.S. (2021), "Disruption in global supply chain and socio-economic shocks: a lesson from COVID-19 for sustainable production and consumption”, Operations Management Research, pp. 1-16, doi: 10.1007/s12063-021-00179-y.

\begin{abstract}
About the authors
Mian M. Ajmal is an Associate Professor of Management at the Abu Dhabi University, Abu Dhabi, UAE. He also holds Research Fellowship position at the Industrial Management Department, University of Vaasa, Finland. He obtained his Doctoral degree in Business Administration and Economics from the University of Vaasa, Finland. He has been involved in several European Union research projects in the past. His research interests pertain to knowledge, project and supply chain management, entrepreneurship, sustainability and organizational behavior and culture. He has published more than 60 research articles in several internationally well-known journals.

Mehmood Khan is an Associate Professor of Management at the Abu Dhabi University and has served as the Director of the Center of Excellence in Sustainable Business Processes at the Abu Dhabi University. He holds a Ph.D. in Industrial Engineering from Ryerson University, Canada. He has taught various courses in Operations Research/Management and Supply Chain Management at King Fahd University, Saudi Arabia; Brock University, Canada; Ryerson University, Canada. His research interests span role of technology, internet of things, quality control, and sustainable supply chains. His work has been published in various top ranked journals.

Muhammad Kashif Shad is a Lecturer at Management and Humanities Department, Universiti Teknologi Petronas (UTP) Malaysia. He earned his Ph.D. in Management and M.Phil. in Management degree with concentration in Enterprise Risk Management from Management and Humanities Department, UTP Malaysia. He obtained his Bachelor of Business Administration (BBA) degree with concentration in Finance from Hazara University Mansehra, Pakistan in 2012. He has published more than 25 articles in indexed journals and presented papers in local and international conferences. His research interests are in the area of Enterprise Risk Management (ERM), Economic Value-Added Analysis (EVA), and Corporate Sustainability. Muhammad Kashif Shad is the corresponding author and can be contacted at: kashif.shad@utp.edu.my
\end{abstract}

For instructions on how to order reprints of this article, please visit our website:

www.emeraldgrouppublishing.com/licensing/reprints.htm

Or contact us for further details: permissions@emeraldinsight.com 